\title{
Menuju Indonesia Emas Dalam Perspektif Pendidikan Islam
}

\author{
SYAUKANI \\ UIN Sumatera Utara \\ Jl. Willem Iskandar Pasar V Medan Estate, 20371 \\ e-mail: sknhasbi@gmail.com
}

\begin{abstract}
Absrtak: Kurangnya perhatian pemerintah dalam prioritas pembangunan di bidang pendidikan mengakibatkan negara ini menjadi negara yang masyarakatnya kurang menguasai tekhnologi yang terus berkembang pesat (masyarakatnya bersifat konsumtif saja), yang hanya dapat memakai tekhnologi yang diciptakan negara lain tanpa dapat menciptakan tekhnologi asli made in Indonesia. Bahkan yang cukup memprihatinkan hanya dapat memakai barang yang sudah tidak dipakai lagi dinegara lain (barang bekas), seperti import pesawat bekas, bus-bus dan truk-truk serta alat berat lainnya yang second hand.
\end{abstract}

Kata kunci: Indonesia Emas, Perspektif Pendidikan Islam

\section{PENDAHULUAN}

Sudah 71 tahun Indonesia merdeka namun masih belum juga dapat memberikan kecerdasan, kesejahteraan, ketentraman, keadilan dan kebahagiaan kepada rakyatnya sebagaimana yang tertuang dalam Pembukaan Undangundang Dasar Negara Republik Indonesia tahun 1945. Malah menurut pemberitaan akhir-akhir ini yang dapat di baca, di dengar dan lihat melalui media cetak dan elektronik, banyak rakyat yang menganggur tidak mendapat pekerjaan, bahkan banyak diantara mereka adalah orang-orang yang berpendidikan tinggi (sarjana), banyak rakyat yang susah menghidupi keluarganya sehingga ada yang membuang bayi dan bahkan membunuh anak. Pada sisi lain, terdapat balita yang kurang gizi karena orang tua tidak mampu memberikan makanan yang layak dikonsumsi oleh balita tersebut, seperti susu dan makan bergizi lain, dan yang paling menyedihkan berita terakhir adalah banyak rakyat yang mati kelaparan di beberapa daerah di Indonesia, seperti di Papua. Bukankah ini merupakan suatu kemunduran, bahkan lebih mundur lagi dari masa penjajahan dahulu? Kenapa hal ini dapat terjadi?

Banyak kalangan mengatakan bahwa hal ini terjadi karena kesalahan pemerintah dalam memberikan prioritas pembangunan bangsa ini. Pemerintah pada masa sebelum reformasi dan masa reformasi terlalu banyak memberikan perhatian pembangunan dalam bidang ekonomi (economic development) dan kurang memperhatikan pembangunan sumber daya manusia (human resources development). 
Padahal bukti sejarah telah memperlihatkan bahwa pambangunan yang terakhir inilah yang dapat membawa suatu bangsa itu menjadi bangsa yang maju dan terhormat dan beradab. Sebagai contoh Singapura, Jepang, Korea dan lainnya. Apa yang terjadi di Indonesia adalah ketimpangan atau ketidak merataannya pembangunan di Indonesia. Sebagai kenyataan yang dapat dilihat saat ini ada daerah yang mendapat pembangunan yang pesat dan baik sedangkan di daerah lain kurang mendapat perhatian. Ada sebagian daerah yang maju sedangkan daerah lainnya tetap tertinggal bahkan seperti di Papua masih banyak yang memakai koteka, bukan mereka tidak mau meninggalkan adat istiadat tersebut, tapi memang kondisi pembangunan belum merata sampai kesana. Bahkan yang ironisnya pemerintah pusat hanya mengambil kekayaan hasil bumi suatu daerah tapi kurang memperhatikan pembangunan di daerah tersebut, kekayaan yang didapat kebanyakan dipergunakan untuk pembangunan pada pusat pemerintahan.

Pembangunan ekonomi yang telah diprioritaskan pemerintah, yang telah menyedot keuangan negara yang cukup besar, bahkan meninggalkan hutang yang cukup besar kepada negara-begara yang telah memberikan bantuan hutang, namun ternyata tidak juga dapat membawa bangsa ini kepada bangsa yang maju dalam bidang perekonomian, malah sebaliknya bangsa yang terpuruk dimana sekarang negara Indonesia merupakan negara yang paling banyak hutangnya dan mengalami kesulitan dalam membayar hutang sehingga harus meminjam lagi untuk membayar bunga pinjaman tersebut.
Akibatnya pembangunan dibidang lainnya kurang memdapat perhatian, misalnya pembangunan bidang pendidikan.

Kurangnya perhatian pemerintah dalam prioritas pembangunan di bidang pendidikan mengakibatkan negara ini menjadi negara yang masyarakatnya kurang menguasai tekhnologi yang terus berkembang pesat (masyarakatnya bersifat konsumtif saja), yang hanya dapat memakai tekhnologi yang diciptakan negara lain tanpa dapat menciptakan tekhnologi asli made in Indonesia. Bahkan yang cukup memprihatinkan hanya dapat memakai barang yang sudah tidak dipakai lagi dinegara lain (barang bekas), seperti import pesawat bekas, bus-bus dan truk-truk serta alat berat lainnya yang second hand. Jadi selama 71 tahun Indonesia merdeka manusia Indonesia belum mampu menjadikan negeri ini manjadi negeri maju, negeri yang adil dan makmur seperti yang telah dicita-citakan para pejuang kemerdekaan Republik Indonesia. Mengapa semua ini terjadi? Ini adalah akibat kekeliruan para pemimpim atau para wakil rakyat yang duduk di pemerintahan, mereka terlalu memfokuskan pembangunan negeri ini pada pembangunan infra struktur dan pembangunan sektor ekonomi (economic development) dan kurang sekali memperhatikan pembangunan sumber daya manusia (human resources development) terutama dalam bidang pendidikan. Padahal pembangunan manusia diakui banyak orang akan memberikan dampak positif terhadap kemajuan suatu bangsa.

Oleh karenanya jalan yang paling baik yang harus dilakukan untuk saat ini bagi Indonesia agar dapat mengejar ketertinggalan dari 
negara-negara lain, dan seperti juga yang telah lama dilakukan oleh negara-negara maju, adalah memfokuskan kepada pembangunan bidang pendidikan anak bangsa. Seperti dikatakan oleh Tilaar "dewasa ini tidak ada suatu negara dan pemerintahan di dunia ini yang tidak menjadikan pendidikan sebagai sarana untuk mengubah kehidupan rakyatnya menuju kepada kehidupan sosial yang lebih baik" (H.A.R.Tilaar, 2002: 6). Oleh karena itu keberhasilan pembangunan dalam bidang pendidikan ini kelak dapat dipastikan akan membawa Indonesia menuju masa keemasannya, Insya Allah. Dan yang menjadi pekerjaan rumah (PR) negara ini adalah menjawab pertanyaan apa yang dapat dan harus dilakukan pemerintah dalam pembangunan bidang pendidikan dan bagaimana caranya?

\section{PENGERTIAN INDONESIA EMAS}

Emas adalah suatu logam mulia yang berwarna kekuningkuningan yang merupakan logam yang paling mahal harga diantara logam-logam lain yang ada, seperti besi, timah, tembaga dan suasa. Logam ini banyak disenangi dan dipergunakan orang, terutama kaum perempuan, karena keindahan dan bernilai tinggi. Bahkan emas juga menjadi nilai tukar yang amat penting dalam perekonomian dunia.

Dalam bidang olah raga, memperoleh emas atau medali emas (gold medal), merupakan suatu prestasi yang amat membanggakan, prestasi nomor satu yang dicari setiap atlet pada setiap event-event pertandingan. Bahkan untuk maksud ini setiap negara menghabiskan banyak tenaga dan biaya untuk pembinaan atlet-atletnya agar kelak dalam pertandingan memperoleh juara pertama yakni memperoleh medali emas. Pemerintah Indonesia masuk negara dua besar tertinggi di dunia dalam memberikan bonus pada Olimpiade Rio De Janeiro 2016 lalu bagi atlet yang bisa meraih emas even olimpide dunia, yakni sebesar Rp 5 milliar, di bawah Singapura Rp. 9.75 miliar. Dengan adanya perolehan medali emas, apalagi medali emas terbanyak, dalam suatu event, terlebih-lebih event olimpiade, hal ini akan meningkatkan martabat (prestige) dan gengsi suatu negara. Oleh karena itu 'emas' merupakan barang mahal dan berharga yang setiap orang pasti akan senang mendapatkannya. Dan tentu untuk mendapatkannya semua orang tahu bahwa mereka harus berusaha dan bekerja keras.

Sejalan dengan dua pengertian 'emas' diatas maka Indonesia emas yang dimaksud dalam tulisan ini adalah usaha untuk terciptanya kehidupan bangsa Indonesia yang cerdas, bangsa yang menghargai manusia sebagai manusia layaknya, manusia yang bermoral religius, berbudi pekerti luhur (insan kamil) serta manusia yang dapat hidup damai dan sejahtera, baik lahir maupun batin. Kehidupan seperti yang dimaksud ini pada intinya sama dengan makna hakiki dari Pembukaan Undangundang Dasar 1945 yang telah ditetapkan oleh pendiri bangsa (Founding Fathers) Indonesia dan sesuai dengan cita-cita luhur seluruh rakyat Indonesia yang tertuang dalam falsafah negara Republik Indonesia yakni falsafah Pancasila.

\section{FALSAFAH NEGARA INDONESIA}

Indonesia sebagai sutau negara yang merdeka memiliki falsafah negara yang disebut Pancasila. Hal ini sesuai dengan yang termaktub 
dalam Pembukaan Undang-undang Dasar 1945 sebagaimana dinyatakan: Kemudian daripada itu untuk membentuk suatu Pemerintahan Negara Indonesia yang melindungi segenap bangsa Indonesia dan seluruh tumpah darah Indonesia dan untuk memajukan kesejahteraan umum, mencerdaskan kehidupan bangsa dan ikut melaksanakan ketertiban dunia yang berdasarkan kemerdekaan, perdamaian abadi dan keadilan sosial, maka disusunlah kemerdekaan kebangsaan Indonesia itu dalam suatu Undang-undang Dasar Negara yang berkedaulatan rakyat dengan berdasarkan kepada: Ketuhanan Yang Maha Esa, Kemanusiaan yang Adil dan Beradab, Persatuan Indonesia dan Kerakyatan yang Dipimpin oleh Hikmah Kebijaksanaan dalam Permu-syawaratan/perwakilan, serta dengan mewujudkan suatu keadilan sosial bagi seluruh rakyat Indonesia.

Berdasarkan ketentuan yuridiskonstitusional ini maka konsekwensi baik formal maupun fungsional untuk mencapai Indonesia yang ideal, yang sesuai dengan cita-cita para founding fathers adalah menjadikan (1) Pancasila sebagai dasar negara atau filsafat Negara Republik Indonesia; (2) Pancasila sebagai norma dasar dan norma tertinggi di dalam negara Republik Indonesia; (3) Pancasila sebagai ideologi negara, ideologi nasional Indonesia; (4) Pancasila sebagai identitas dan karakteristika bangsa atau kepribadian nasional, yang perwujudannya secara melembaga sebagai sistem negara Pancasila; (5) Pancasila sebagai jiwa dan kepribadian bangsa, pandangan hidup (keyakinan bangsa) yang menjiwai sistem kenegaraan dan kemasyarakatan Indonesia. Karena itu Pancasila adalah sistem filsafat Indonesia yang potensial dan fungsional, yang normatif ideal (Syam, 1983: 346).

Pada dasarnya ketentuan yuridiskonstitusional di dalam Pembukaan Undang-undang Dasar 1945 bahwa Pancasila sebagai Dasar negara Republik Indonesia adalah diangkat dari realitas sosio-budaya dan tatanilai dasar masyarakat Indonesia. Nilai-nilai dasar ini telah menjiwai bangsa dan merupakan perwujudan kepribadian bangsa Indonesia. Jika nilai-nilai ini dipedomani dengan sebaik-baiknya dan sebenarbenarnya oleh semua anak bangsa ini mulai dari pimpinan pemerintahan sampai kepada rakyat biasa maka bukan mustahil tujuan pembangunan yang dicita-citakan akan terwujud karena sebenarnya negara Indonesia merupakan negara yang cukup makmur andai manusia-manusia yang ada di negara ini dapat mengelolanya dengan arif.

Indonesia merupakan negara yang cukup kaya, kaya dalam sumber daya alam, sumber laut dan hutan yang luas yang masih belum digali dan dikelola dengan baik kekayaan yang terkandung di dalamnya. Negeri yang subur dan memiliki puluhan ribu pulau, yang kebanyakan dari pulau tersebut belum tersentuh tangan-tangan manusia. Tambahan dari itu, Indonesia juga memiliki budaya yang cukup kaya, budaya dari berbagai etnis dan suku yang mendiami nusantara ini yang dapat menjadi daya tarik bagi industri pariwisata. Mengapa kemakmuran atau zaman keemasan belum terwujud di negeri ini? Bagaimana mewujudkannya? Sebelum menjawab pertanyaan ini ada baiknya terlebih dahulu kita melihat kondisi bangsa saat ini. 


\section{PEMBANGUNAN INDONESIA EMAS}

MENUJU

Dari segi ontologi Indonesia emas yang dimaksudkan di sini yakni manusia Indonesia seutuhnya, manusia yang lengkap aspek-aspek kepribadiannya, yaitu manusia yang berakhlak mulia dalam kehidupan sebagai warga masyarakat dan yang mempunyai ciri warga yang baik (good citizenship). Manusia Indonesia emas ini dapat terwujud jika diberikan bekal ilmu pengetahuan yang baik dan benar, yang memperhatikan seluruh aspek yang ada pada manusia sebagai makhluk sosial dan juga sebagai makhluk yang fitri (mengambil istilah agama), yakni sebagai sifat alami pembawaan manusia (fitrah/innate nature).

Seperti sudah disinggung di atas bahwa pembangunan dalam bidang pendidikan merupakan kunci sukses untuk menuju keemasan suatu negara. Contoh yang dapat diambil hikmahnya dari apa-apa yang telah dicapai oleh negara-negara maju saat ini tiada lain karena perhatian penuh kepada pembangunan bidang pendidikan. Amerika, misalnya, negara ini merasa "iri" dengan kemajuan yang telah dicapai Rusia pada tahun 1959 karena Rusia telah dapat menciptakan dan meluncurkan Sputnik I. Salah satu yang mereka kecewakan pada saat itu adalah mutu pendidikan di negara tersebut. Mengetahui hal ini maka pemerintah Amerika memberlakukan ketetapan yang disebut dengan "Manpower Development Training Act" yakni memberikan kesempatan kepada dunia pendidikan untuk menemukan metode-metode baru dalam memperbaiki mutu pendidikan. Utuk maksud tersebut maka dilakukan beberapa penelitian yang kemudian ditemukan tehnik-tehnik baru dalam pengajaran, seperti tehnik yang disebut dengan Competency Based Education dan Mastery Learning. Untuk kepentingan ini pemerintah mengeluarkan dana yang cukup besar, trilliunan dolar. Dan hasilnya cukup memuaskan, karena tidak lama kemudian yakni pada tahun 1965-1970 Amerika sudah dapat mendaratkan Apollo 11 di bulan.

Contoh lain, Malaysia, pada tahun 1970an hingga 1980an banyak sekali pelajar negeri jiran tersebut yang menuntut ilmu di negara-negara maju dan juga menuntuk ilmu di Indonesia, terutama ilmu agama Islam. Tambahan dari itu, banyak sekali guru-guru bangsa Indonesia yang diundang untuk mengajar disana. Apa yang terjadi tak lama kemudian adalah malah kebalikannya, yakni banyak pelajar dari Indonesia yang menuntut ilmu di negeri Malaysia dan banyak guru bangsa Malaysia yang mengajar di Indonesia. Dan sampai kini pembangunan di Malaysia begitu pesat dan maju sehingga negara ini di juluki sebagai salah satu negara "macan Asia". Hal ini terjadi karena pemerintahan Malaysia memberikan perhatian yang cukup besar kepada pembangunan manusia, menyiapkan dana APBN yang cukup besar untuk pembangunan dalam bidang pendidikan.

Apakah Indonesia belum melaksanakan pembangunan di bidang pendidikan? Indonesia sudah melaksanakan pembangunan pendidikan, sudah banyak program yang di ajukan, sudah banyak sekolah yang dibangun, seperti 
sekolah-sekolah Inpres, sudah banyak program-program yang dilakukan dalam rangka peningkatan mutu pendidikan, seperti mastery learning, vocational education, human engineering, CBSA, Management Berbasis Sekolah, Kurikulum 2013, dan banyak lain-lainnya, sampai yang terakhir program otonomi pendidikan, namun semua yang telah dilaksanakan belum memperoleh hasil yang baik, mutu pendidikan di Indonesia tetap kalah bersaing dengan negara-negara tetangga atau sesama negara ASEAN.

Kenapa hal ini terjadi? Berbagai kemungkinan jawaban dapat di munculkan, diantaranya mungkin kesalahan pada sistem pendidikan yang ada, mungkin juga kesalahan pada metode yang dipakai, dan mungkin pula karena mental pelaksana pebangunan bangsa ini yang bobrok, yang telah menyalah gunakan dana bantuan pembangunan, sehingga pelaksanaan di lapangan tidak dapat berjalan sesuai dengan yang telah direncanakan. Hal ini semua timbul karena mental anak bangsa yang korup, materialisme, feodalisme, hedonisme, dan banyak lagi isme-isme lainnya.

Hasil survey Lembaga

Transparansi Internasional menunjukkan bahwa korupsi dipraktekkan secara sistematis dengan melibatkan pelaku yang semakin luas, tidak hanya dikalangan pemerintahan dan swasta, tapi juga di lingkungan Lembaga Swadaya Masyarakat (LSM), dan bahkan di lembaga keagamaan termasuk di lembagalembaga pendidikan di Indonesia. Survey terakhir Transparency International tahun 2015 menunjukkan posisi Indonesia masih berada pada posisi yang menyedihkan dalam "kelompok negara terkorup". Walaupun tidak lagi menjadi negara nomor terakhir karena berada pada peringkat ke 88 dari 168 negara yang disurvey. Walaupun skor Indonesia naik 2 poin dan naik 19 peringkat dari tahun sebelumnya, kenaikan tersebut belum mampu manyaingi peringkat yang dimiliki oleh Malaysia (50), dan Singapura (85).

Banyak kalangan meyakini bahwa penyebab terjadinya hal yang dikemukakan diatas adalah kurang berhasilnya pendidikan di Indonesia dalam menanamkan nilai-nilai pendidikan yang seutuhnya dan nilai-nilai moral yang religius dan berkarakter kepada anak bangsa ini. Sekolah telah membelenggu masyarakat seperti yang dikemukakan oleh Ivan Illich dalam Deschooling Society, atau dalam istilah Neil Postman "pendidikan sudah mati" (the End of Education), dan dalam istilah Paulo Freire "Pendidikan yang Tertekan" (Pedagogy of the Opressed). Oleh karenanya mau tidak mau perlu ada revolusi dalam pedagogi di Indonesia. Bagaimana seharusnya pendidikan dilaksanakan di negara ini?

Sebagaimana dikemukan para ahli bahwa pendidikan adalah suatu proses belajar dan penyesuaian individu-individu secara terus menerus terhadap nilai-nilai budaya dan cita-cita masyarakat; suatu proses dimana suatu bangsa mempersiapkan generasi mudanya untuk melanjutkan kehidupan dan untuk memenuhi tujuan hidup secara efektif dan efisien. Dalam kaitan ini tokoh pendidikan Indonesia, Ki Hajar Dewantara, menyatakan bahwa pendidikan umumnya berarti daya 
upaya untuk memajukan budi pekerti (kekuatan batin), pikiran (intellect) dan jasmani anak-anak selaras dengan alam dan masyarakatnya. Sementara menurut Mohammad Natsir dalam tulisannya "Idiologi Didikan Islam" menyebutkan bahwa pendidikan adalah suatu pimpinan jasmani dan ruhani yang menuju kepada kesempurnaan dan kelengkapan arti kemanusiaan dengan arti sesungguhnya (Azra, 1998: 3-4). Selanjutnya Undang-Undang Republik Indonesia nomor 20 Tahun 2003 tentang Sistem Pendidikan Nasional Bab II, Dasar Fungsi, dan Tujuan pasal 2 bahwa "pendidikan nasional berdasarkan Pancasila dan Undang-undang Dasar Negara Republik Indonesia Tahun 1945". Kemudian dalam pasal 3 disebutkan pendidikan nasional berfungsi mengembangkan kemampuan dan membentuk watak serta peradaban bangsa yang bermartabat dalam rangka mencerdaskan kehidupan bangsa, bertujuan untuk berkembangnya potensi peserta didik agar menjadi manusia yang beriman dan bertaqwa kepada Tuhan Yang Maha Esa, berakhlak mulia, sehat, berilmu, cakap, kreatif, mandiri, dan menjadi warga negara yang demokratis serta bertanggung jawab. (Azra, 1998: 5).

Untuk menciptakan manusia seperti yang dikemukakan diatas maka pendidikan harus mengacu kepada teori-teori pendidikan yang mutakhir. Dalam teori pendidikan ada tiga domain dalam taksonomi tujuan pendidikan. Pertama, domain kognitif yang menekankan aspek untuk mengingat dan mereproduksi informasi yang telah dipelajari, yaitu untuk mengkombinasikan cara-cara kreatif dan mensintesakan ide-ide dan materi baru. Kedua, domain afektif yang menekankan aspek emosi, sikap, apresiasi, nilai atau tingkat kemampuan menerima atau menolak sesuatu. Ketiga, domain psikomotorik yang menekankan pada tujuan untuk melatih keterampilan seperti menulis, tehnik mengajar, berdagang, dan lain-lain (Bloom, 1973: 6-7). Ketiga domain itu idealnya selaras dan saling melengkapi.

$$
\text { Kenyataannya hubungan }
$$

antara perubahan sikap (afeksi) dan meningkatkan ilmu pengetahuan (kognitif) secara statistik cenderung berdiri sendiri. Berdasarkan temuan Mayhew, hubungan antara ketiga domain itu sangat rendah untuk memprediksi salah satu domain secara efektif meresponi dan diresponi domain lainnya (Bloom, 1973: 6-7). Karena itu dalam menyelenggarakan pendidikan, jika dilihat dari tiga kerangka domain pendidikan, ada hal hal sangat problematis, cenderung tidak terjadi keselarasan perimbangan antara ketiga aspek domain pendidikan itu; terlihat kecenderungan salah satu aspeknya terabaikan dan aspek lainnya lebih dominan. Padahal menurut ahli pendidikan Islam, Omar Mohammad al-Thoumy al Syaibani, keselarasan itu harus menunjang: Pertama, tujuan individual yaitu berkaitan dengan individu-individu, pelajaran (learning) dan dengan pribadi-pribadi mereka, dan apa yang berkaitan dengan individuindividu tersebut pada perubahan yang diinginkan dalam tingkah laku, aktivitas dan pencapaiannya, dan pada pertumbuhan yang diingini pada pribadi mereka, dan apa persiapan yang diharuskan kepada mereka pada kehidupan dunia dan akhirat. Kedua, tujuan-tujuan sosial yaitu yang berkaitan dengan kehidupan masyarakat secara 
keseluruhan, dengan tingkah laku masyarakat umumnya, dan dengan apa yang berkatian dengan kehidupan ini dengan perubahan yang dikehendaki dan pertumbuhan; memperkaya pengalaman dan kemajuan yang diingini. Ketiga, tujuan professional yang berkaitan dengan pendidikan dan pengajaran sebagai ilmu, sebagai seni, sebagai profesi, dan sebagai suatu aktivitas di antara aktivitas-aktivitas masyarakat (Al-Syaibani, 1979: 399). Dari ketiga unsur pencapaian pendidikan itu idealnya harus dilakukan secara terpadu (integral) sehingga tercapai tujuan proses pendidikan yang diinginkan. Dengan demikian, akan jelas ke mana pendidikan itu akan diarahkan.

Namun kecendrungan dan pencapaian pendidikan sudah jauh bergeser dari tujuan idealnya. Tujuan profesional yang lebih menekankan aspek psikomotorik, lebih mendapat tempat dan prioritas dari targettarget kurikulum pendidikan. Lembaga pendidikan, termasuk perguruan tinggi, umumnya seringkali mengarahkan aspek intelektualitas epistemologis dan kompetensi profesionalitas peserta didiknya.

Pada akhirnya, salah satu ukuran keberhasilan bersifat kuantitatif dengan penekanan yang kuat pada profesionalisme menjadi ukuran yang pada akhirnya diterima umum; tinggi rendahnya mutu lembaga pendidikan hanya diukur dari seberapa mudah dan seberapa banyak para lulusan diterima dalam lapangan kerja karena tuntutan profesionalisme. Hal ini menyebabkan lulusan perguruan tinggi cenderung hanya menjadi robot-robot intelektual yang tidak memiliki kepekaan sosial, dan ini memperkuat asumsi bahwa lembaga pendidikan tinggi bak menara gading yang terasing dari masyarakatnya dan tidak membumi.

Sama halnya dengan pendidikan Islam di Indonesia, kondisi seperti yang terjadi pada pendidikan umum terjadi dalam pendidikan Islam yang diperparah adanya kekeliruan persepsi keagaman. Sehingga pendidikan Islam di tanah air menjadi mandeg dan cenderung tidak mampu menghadapi perubahan sosial. Hal demikian itu disebabkan karena persepsi keagamaan yang diajarkan tidak lagi kontekstual dan tidak menyentuh permasalahan kehidupan masya-rakat. Musibah ini terjadi, karena lagi-lagi orientasi pendidikan diarahkan pada pematangan aspek kognisi yang sangat kuat; pada institusi pendidikan sering sekali terjadi mata pelajaran yang terkait dengan upaya pembentukan moralitas (aspek afeksi) cenderung didekati dengan pendekatan kognisi an sich.

Di sisi lain, ukuran keberhasilan pendidikan sampai saat ini masih cenderung instan dengan melegalisasi standar-standar kognisis yang juga kabur. Karena tujuan pendidikan tidak jelas sepenuhnya, sistem dan kurikulum pendidikan juga tidak jelas arahnya. Setiap kali kurikulum pendidikan diubah tanpa penalaran yang jelas, maka yang menjadi korban pertama adalah peserta didik yaitu para siswa dan mahasiswa, dan akhirnya masyarakat secara keseluruhan. Pada akhirnya kebijakan dari penjabaran sistem pendidikan nasional mengabaikan muatan "proses" karena cenderung memprioritaskan hasil akhir. Bahkan lebih parah kecenderunngan mutu pendidikan dihitung dengan muatan kuantitatif statistik an sich untuk 
mengukur suatu keberhasilan pendidikan.

Karena itu Azyumardi Azra, tokoh sejarah dan pendidikan Islam, mantan Rektor Universitas Islam Negeri Syarif Hidayatullah (UIN Syahid) Jakarta, menyarankan pengkajian ulang format pendidikan saat ini. Menurut beliau ada tiga hal yang mempengaruhi problem pendidikan. Pertama, pendidikan tidak dibatasi hanya sebagai schooling belaka (memimjam istilah Ivan Illich). Dengan membatasi pendidikan sebagai schooling, pendidikan terasing dari kehidupan yang nyata dan masyarakat terlempar dari tanggungjawabnya dalam pendidikan. Kedua, pendidikan bukan hanya untuk mengembangkan intelegensi akademik peserta didik. Tujuan pendidikan bukan hanya manusia yang terpelajar tetapi manusia yang berbudaya (educated and civilized human being). Dengan demikian proses pendidikan dapat kita rumuskan sebagai proses hominisasi da humanisasi seseorang yang berlangsung di dalam lingkungan hidup keluarga dan masyarakat yang berbudaya, kini dan masa depan. Ketiga, pendidikan adalah usaha untuk memberdayakan manusia. Manusia yang berdaya adalah manusia yang dapat berfikir kreatif, yang mandiri, yang produktif dan yang dapat membangun dirinya dan masyarakatnya.

Selain pengkajian ulang pendidikan seperti dikemukakan Azyumardi diatas, dapat juga diterapkan pendidikan berbasis agama (syariah). Karena mayoritas penduduk Indonesai adalah masyarakat yang mempercayai adanya Tuhan (Ketuhanan Yang Maha Esa dalam sila pertama), maka pendidikan berbasis agama ini diyakini akan dapat memperbaiki mutu pendidikan dan moral bangsa ini kearah yang dicita-citakan oleh para pejuang bangsa dan founding fathers negara ini sebagai mana tertuang dalam pembukaan UUD 1945. Jika hal ini dapat diwujudkan maka diyakini dengan haqqul yakin Indonesia emas akan dapat terealisir. Bagaimana bentuknya pendidikan berbasis agama/syariah ini? Dalam menjawab hal ini Syahrin mengemukan pendapatnya sebagai berikut ini.

Menurut Syahrin, melihat kondisi dunia yang semakin menglobal, maka yang menjadi fokus masalah adalah "bagaimana memberdayakan manusia Indonesia di era global dengan tetap berpegang teguh pada aturan agama". Aturan agama/syariat di sini dalam arti yang substansial-universal dan tentu tidak sekedar yang dipahami mereka yang berfikir "aturan keagamaan tok". Dengan demikian, pendidikan berbasis agama lebih kurang dapat dipahami sebagai upaya memberdayakan anak didik untuk dapat mewarnai budaya global, jika bukannya memimpinnya, sesuai kompetensi keilmuannya dengan tetap menjadikan religiositas sebagai basisnya. Dalam perspektif ini, selanjutnya dikemukakannya, tujuan pendidikan berbasis agama meliputi hal-hal berikut:

Pertama, tujuan individu yang mencakup: (1) meningkatkan upaya penguasaan ilmu pengetahuan dan teknologi agar anak didik memiliki keunggulan komparatif dan kompetitif di kancah global; (2) menyemai perkembangan yang seimbang bagi setiap individu dengan menyuburkan potensi fitrah beragama, fisik, intelektual, emosi, moral, dan estetika; melembagakan studi masa depan 
pada institusi-institusi pendidikan dan menginternalisasikannya pada diri setiap insan pendidikan. Hal ini penting, mengingat bahwa salah satu faktor penyebab bangsa ini terbelakang adalah kurang terfokus kepada masa depan; (4) menghilangkan pandangan yang dikotomis mengenai ilmu pengetahuan dan kehidupan; (5) mengakses puncak piramida revolusi informasi, dan jika mungkin memimpin proses penggunaannya; (6) pendidikan berbasis agama dimaksudkan untuk meyakinkan semua penganut agama bahwa kemajuan yang dicapai umat manusia saat ini adalah milik bersama umat manusia; (7) melakukan revitalisasi dan modernisasi dalam agama pada berbagai aspeknya.

Kedua, tujuan ekonomi, yaitu membangun sumber daya manusia yang berkualitas perancang dan pelaksana yang cakap, rasional, dan bertanggungjawab untuk memberdayakan diri sendiri, dan memberikan kontribusi bagi pemberdayaan masyarakat, serta kemajuan bangsa dan negara.

Ketiga, membangun individu yang memiliki nasionalisme, setia kepada negara, memiliki patriotisme, serta sadar akan hak dan tanggung jawabnya kepada negara dan bangsanya.

Keempat, tujuan sosial yang mencakup: (1) menegaskan makna dan hakikat nilai kemanusiaan dan kehidupan manusia; (2) memberikan daya banding kepada semua umat beragama agar mereka tidak gugup atau kaget berhadapan dengan kehidupan modern;

menampilkan keberagamaan yang lebih sejuk dan ramah berdasarkan pemahaman terhadap nilai-nilai universal yang diajar agama; (4) pendidikan berbasis agama juga bertujuan untuk penumbuhan kepercayaan diri setiap umat beragama; (5) menumbuhkan persaudaraan/ukhuwah yang lebih universal dan mencakup berbagai segi kehidupan umat manusia; (6) menguapyakanpenghapusan

kemiskinan dan ketimpangan sosial secara sungguh-sungguh (Syahrin Harahap, 2005: 37-38).

Dari ungkapan diatas jelas bahwa perubahan kehidupan masyarakat menuju kepada kehidupan yang manusiawi, bermoral dan sesuai dengan cita-cita bangsa menjadikan "manusia seutuhnya" hanya akan tercapai jika materi pengetahuan yang ditransfer adalah ilmu pengetahuan yang benar menurut aturan agama. Dalam hal ini tidak dikenal adanya dikotomi antara ilmu pengetahuan agama dan pengetahuan umum. Dengan demikian, setiap informasi keilmuan adalah ilmu yang berbasis kepada kitab suci atau berbasis kepada petunjuk Tuhan Yang Maha Esa. Mengapa harus demikian?

Sejarah umat manusia menunjukkan bahwa banyak orang yang berilmu melakukan pelanggaran moral. Mulai dari tidak mengamalkan ilmunya, melacurkan keilmuannya, menodai kejernihan ilmu yang dimilikinya dengan perilaku-perilaku yang tidak sesuai dengan nilai dan pesan ilmunya, hingga perilaku yang sangat merugikan masyarakat, seperti KKN, menjual teori untuk kepentingan penjajahan, dan yang membiarkan penemuan ilmu pengetahuan menjadi alat penindasan bagi manusia lain, atau eksploitasi tanpa batas terhadap alam dan lingkungan hidup hingga merusak ekosistem. Hal ini lah yang terjadi dinegara ini dewasa ini, ketika sebagian orang 
yang berilmu tidak berprilaku sejajar dengan ilmu yang dimilikinya. Keadaan ini lalu menimbulkan kekecewaan, lalu muncullah statement yang mengatakan "saat ini kita membutuhkan orang yang baik, yang bermoral, berakhlak, bukan orang yang pintar". Statement ini tentu ada benarnya dan ada juga ketidak benarannya, karena seseorang tidak dapat menjeneralisasikan hal tersebut. Kebutuhan kita terhadap keberilmuan merupakan keniscayaan, apalagi hal itu merupakan salah satu perintah agama. Akan tetapi, yang menjadi lebih krusial adalah bagaimana agar ilmu yang dimiliki seseorang di backup oleh moral atau akhlaknya.

Islam memberikan solusinya, seperti yang dikemukakan dalam Alquran al-Karim bahwa Allah menempatkan para ilmuan pada posisi yang tinggi,

Hai orang-orang yang beriman, apabila dikatakan kepadamu "berlapang-lapanglah dalam majelis", maka lapangkanlah, niscaya Allah akan melapangkan tempat untukmu. Dan apabila dikatakan "berdirilah kamu, maka berdirilah", niscaya Allah akan meninggikan orang-orang yang beriman diantaramu dan orangorang yang berilmu pengetahuan beberapa derajat. Dan Allah Maha Mengetahui apa yang kamu kerjakan" (QS AlMujâdalah [58]: 11).

Akan tetapi, posisi strategis tersebut dibarengi dengan keharusan penegakan keimanan, ketaqwaan, dan penegakan moral, sebab kitab suci ini memandang orang yang berilmu sebagai komunitas paling bertaqwa kepada Tuhan. Seperti disebutkan

Dan demikian pula diantara manusia, binatang-binatang melata dan binatang-binatang ternak ada yang bermacammacam warnanya dan jenisnya. Sesungguhnya yang takut kepada Allah diantara hambahamba-Nya, hanyalah ulama. Sesungguhnya Allah Maha Kuasa lagi Maha Pengampun (QS Fâthir [35]:28).

Berdasarkan kemestian logika semacam ini, maka Islam, menempatkan penegakan moral di atas ilmu pengetahuan sebagaimana statement yang sangat terkenal di kalangan umat ini "Moralitas berada di atas ilmu".

Penempatan moralitas di atas ilmu memiliki relevansi yang yang tinggi dengan filsafat ilmu itu sendiri sebab filsafat ilmu memandang bahwa suatu ilmu harus memiliki kriteria ontologi, epistimologi, dan aksiologi. Kriteria yang disebut terakhir jelas memandang keniscayaan ilmu bagi kesejahteraan umat manusia.

Dalam konteks ini misi seorang ilmuan menjadi ganda: pada satu sisi ia menjadi komunitas "pencerah" masyarakat dan pada sisi yang sama ia menjadi "penshaleh" bagi masyarakat. Apabila keadaan ini tidak berjalan dengan seimbang, maka ketinggian nilai ilmu pengetahuan menjadi hilang maknanya. Ilmu yang dapat mencerahkan tetapi tidak dapat menshalehkan akan melahirkan manusia cerdas, tetapi jahat. Sebaliknya, manusia yang hanya bermoral tetapi tidak berilmu sering kali akan menjadi objek dan komoditas yang selalu diperalat dan diombang-ambingkan pihak lain. 
Menghindari kecendrungan ini, para pemikir muslim melihat agama berfungsi sebagai pedoman moral dan siyâsah. Muhammad Arkoun, misalnya, menganalisis Islam dalam konteks ini sebagaimana terlihat dalam bukunya yang terkenal Al-Islam wa al-Siyâsah (Arkoun, 1992).

Dalam perspektif Islam, ciri yang menonjol bagi ilmu pengetahuan adalah hubungannya dengan amal sebab amal terangkum dalam makna 'alim itu sendiri. 'Alim ialah kata yang bukan saja bermakna "seseorang yang memiliki ilmu" tetapi dalam bentuk nahunya (tata bahasa Arab) bermakna "seseorang yang bertindak sesuai dengan ilmu". Menurut Wan Mohammad seorang "alim boleh dikatan seorang yang senantiasa beramal dengan ilmunya" (Wan Daud, 1992: 114). Sejalan dengan ini, dalam perspektif kepercayaan bangsa Cina disebut dengan membentuk manusia 'super'. Konsep manusia 'super' ini dikemukakan oleh Kung-Fu-tzu, filosof termasyuhur Cina. Dia mementingkan pendidikan yang ditujukan untuk membentuk manusia 'super', manusia yang mempunyai sifat-sifat luhur, bijaksana, berprike-manusiaan dan kesatria yang dimotivasi oleh kebenaran bukannya keuntungan serta yang mempelajari jalan dan mencintai manusia.

Oleh karenanya, jika seluruh yang bertanggung jawab atas pelaksanaan pendidikan di Indonesia, baik itu pemerintah seluruh anggota masyarakat yang terlibat, harus dapat mengarahkan terciptanya manusia ilmuan, manusia yang 'alim', atau manusia 'super' dalam filsafat Cina. Dengan terciptanya manusia seperti yang dikemukakan ini maka besar kemungkinan Indonesia akan menjadi negara yang adil dan makmur, kekayaan yang ada dapat dibagi merata kepada semua warga negara, dan akhirnya cita-cita para founding fathers akan menjadi kenyataan dan Indonesia emas akan dapat terjelmakan.

\section{SIMPULAN}

Pembangunan utama suatu peradaban bangsa adalah pembangunan dalam bidang pendidikan. Karena sejarah telah membuktikan bahwa pendidikan mampu menjadikan suatu bangsa yang maju dan makmur. Oleh karena itu untuk menciptakan kemakmuran di Indonesia salah satu jalan yang harus diperbaiki oleh semua warga negara ini adalah perubahan dalam bidang pendidikan Pendidikan harus mampu melakukan empowerment dan transformation bagi masyarakat melalui berbagai program yang mencerminkan adanya inisiatif perbaikan sosial. Pendidikan perlu dimaknai dan dimanfaatkan sebagai instrumen, selain harus mampu menstransformasikan nilai-nilai moral, juga berfungsi melakukan social engineering guna membangun sosial kapital yang efektif dan seimbang.

Melalui pendidikan yang benar maka penegakan moral yang merupakan kebutuhan yang sangat urgent dalam rangka mengawal perjalanan bangsa, dapat terwujudkan. Dengan demikian jatidiri sebagai bangsa yang religius dan berbudaya, seperti tercantum dalam pembukaan Undang-undang Dasar 1945 akan tetap dapat dipertahankan. Dari itu pendidikan yang dibarengi dengan pengetahuan agama memiliki peluang yang sangat strategis dalam membawa bangsa ini menuju keemasannya, 
karena dengan berilmu yang diikuti dengan moral maka seseorang akan bertindak sesuai dengan ilmu. Dan seseorang yang bertindak dengan ilmu tersebut akan menjadi "pencerah dan sekaligus "penshaleh" bagi bangsanya.

\section{DAFTAR RUJUKAN}

Azyumardi Azra, 1998. Esei-esei Intelektual Muslim dan Pendidikan Islam, Jakarta: Logos Wacana Ilmu.

Benyamin S Bloom et.al. 1973. Taxonomy of Educational Objectives, London: Longman Group Limited.

H.A.R.Tilaar, 2002. Perubahan Sosial dan Pendidikan: Pengatar Pedagogi Transformatif untuk Indonesia, Grasindo, Jakarta.

Henderson, SVP, 1954. Introduction to Philosophy of Education. Chicago: Univ. of Chicago Press,.

Ki Hajar Dewantara, 1950. Dasardasar Perguruan Taman Siswa, DIY:Majelis Luhur.

Kuhn, Ts, 1969. The Structure of Scientific Revolution, Chicago: Chicago Univ.,.

Langeveld, MJ, 1955. Pedagogik Teoritis Sistematis (terjemahan), Bandung, Jemmars.

Liem Tjong Tiat, 1968. Fisafat Pendidikan dan Pedagogik, Bandung, Jurusan FSP FIP IKIP Bandung,.

Muhammad Arkoun, 1992. Akhlaq wa al-Siyâsah, UNESCO.

Muhammad Noor Syam, 1983. Filsafat dan Dasar Filsafat Pendidikan Pancasila, Usaha Nasional, Surabaya.

Nurcholish Madjid, dkk, 1995. Kontekstualisasi Doktrin Islam dalam Sejarah, Yayasan Paramadina, Jakarta.
Omar Mohammad al-Toumy alSyaibani, 1979. Falsafah Pendidikan Islam, terj. Hasan Langgulung, Jakarta, Bulan Bintang.

Sindhunata, 2000. Menggagas Paradigma Baru Pendidikan : Demokrasi, Otonomi, Civil Society, Globalisasi, Kanasius, Yogyakarta.

Syahrin Harahap, 2005. Penegakan Moral Akademik di Dalam dan Diluar Kampus, Rajawali Press, Jakarta.

Undang-Undang Republik Indonesia nomor 20 Tahun 2003.

Wan Moh. Nor Wan Daud, 1992. The Concept of Knowledge in Islam, London: Mansell Publishing Limited. 